\title{
One-Stage Transthoracic Operation in Pulmonary, Pericardial and Hepatic Hydatid Cysts
}

\author{
Pulmoner, Perikardial ve Hepatik Kist Hidatikte
}

Tek Basamak Transtorasik Operasyon

\author{
Yener Aydın' ${ }^{1}$ Abdurrahim Çolak², Necip Becit' ${ }^{2}$, Atila Türkyılmaz', Atilla Eroğlu' \\ ' Atatürk Üniversitesi Tıp Fakültesi, Göğüs Cerrahisi Anabilim Dalı, Erzurum \\ ${ }^{2}$ Atatürk Üniversitesi Tıp Fakültesi, Kalp Ve Damar Cerrahisi Anabilim Dalı, Erzurum
}

\begin{abstract}
Our country is an endemic location for hydatid cysts. Echinococcus granulosus can involve all organs in body being frequently liver and lungs. Multiple organ involvement occurs in approximately one third of cases. Occasionally, challenges may occur in surgical treatment of multiple hydatid cyst and several occasions of surgical procedures may be required. In this study, we present a case of right pulmonary, pericardial and hepatic hydatid cysts in which we performed surgery with a one-stage transthoracic approach.
\end{abstract}

Keywords: Echinococcosis, treatment

Aplication: 10.08 .2011

Accepted: 09.09.2011

\section{Özet}

Ülkemiz kist hidatik için endemik bir bölgedir. Echinococcus granulosus en sık karaciğer ve akciğer olmak üzere tüm organları tutabilmektedir. Olguların yaklaşık üçte birinde multipl organ tutulumu görülmektedir. Multipl kist hidatiğin cerrahi tedavisinde zorluklarla karşılaşılabilmekte ve birkaç seans cerrahi işlem gerekebilmektedir. Bu çalışmada tek basamakta transtorasik yaklaşım ile cerrahi uyguladığımız sağ akciğer, perikardial ve karaciğer kist hidatikli bir olguyu sunduk.

Anahtar Kelimeler: Ekinokokkozis, tedavi

Başvuru Tarihi: 10.08.2011 Kabul Tarihi: 09.09.2011

\section{Introduction}

Hydatid cyst is a tissue infestation caused by larval forms of echinococcus granulosus. It may occur at any site of the body. The most common two organs of involvement for hydatid cyst are liver and lungs with incidences of 50$80 \%$ and $10-40 \%$, respectively ${ }^{1,2}$. Cardiac hydatid cyst is rare and consists $0.5-2 \%$ of all hydatid cysts ${ }^{3}$. Multiple organ involvement is seen in approximately one third of hydatid cyst cases ${ }^{4}$. Occasionally, several sessions of surgical procedures may be required in the treatment of hydatid cyst with multiple organ involvement. In this study, we present a case of right pulmonary, pericardial and hepatic hydatid cysts in which we performed surgery with a one-stage transthoracic approach.

\section{Case report}

An eleven years old male patient admitted to our clinic with complaints of persistent fever and cough present 
for one month. Physical examination, routine blood tests and electrocardiography revealed no pathological finding. Coin lesions with regular borders were identified in lungs bilaterally using postero-anterior (PA) chest radiography (Figure 1). Magnetic Resonance Imaging (MRI) showed images sized $45,5 \times 36 \mathrm{~mm}$ in apicoposterior segment of upper lobe of the right lung and sized $20 \times 18,8 \mathrm{~mm}$ at the superior of lower lobe of the left lung being consistent with hydatid cyst. A hydatid cyst sized 38x20 mm was observed in pericardium adjacent to right ventricle and right atrium (Figure 2). Two type 1 hydatid cysts were observed in the liver being at most $4 \mathrm{~cm}$ in diameter in the 7th and 8th segments of the right lobe, $4,5 \mathrm{~cm}$ in diameter in $4 \mathrm{a}$ and $32 \mathrm{~mm}$ in diameter in $4 \mathrm{~b}$, and being at most $3,5 \mathrm{~cm}$ in size in the 6 th segment (Figure 3). A hydatid cyst with diameter of $3 \mathrm{~cm}$ was seen in the upper pole of the left kidney. A pericardial cystic lesion of $28.2 \times 31.2 \mathrm{~mm}$ which was located in right position was identified in echocardiography.

Figure 1: X-ray chest showing bilaterally coin lesions

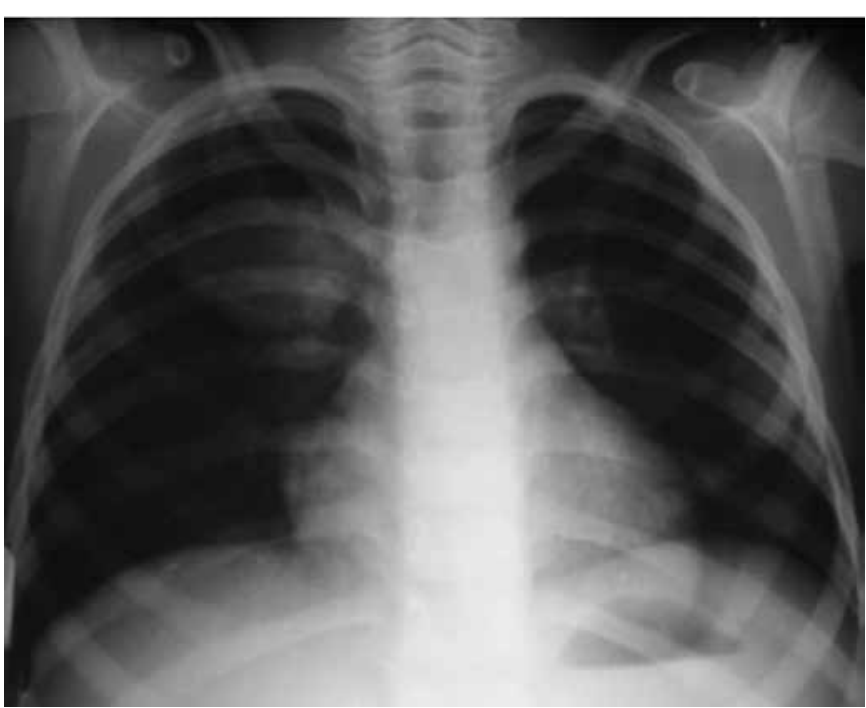

Right thoracotomy approach was used in this patient. We opened the pericardium and drained the pericardial cyst and removed the membrane. Cavity of the cyst was cleared with Povidone-lodine impregnated sponges. Cystotomy and capitonnage was performed for the cyst located in the upper lobe of the lung. Cystotomy was performed in transdiaphragmatic route for liver dome cysts. Diaphragm was repaired primarily by placing an abdominal drain. Subsequently, thorax was closed following the insertion of a thoracic drain. Albendazole treatment was initiated on day 7 postoperatively and the patient was discharged with referral to Pediatric Urology for renal cyst.

Figure 2: A hydatid cyst showing pericardium adjacent to right ventricle and right atrium

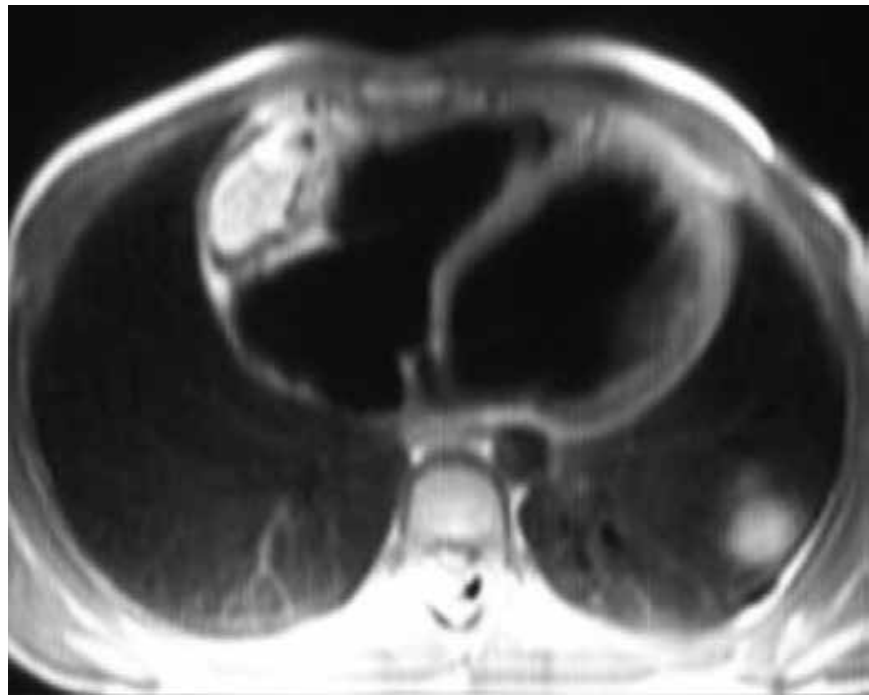

Figure 3: Thoracic CT showing multiple liver cysts

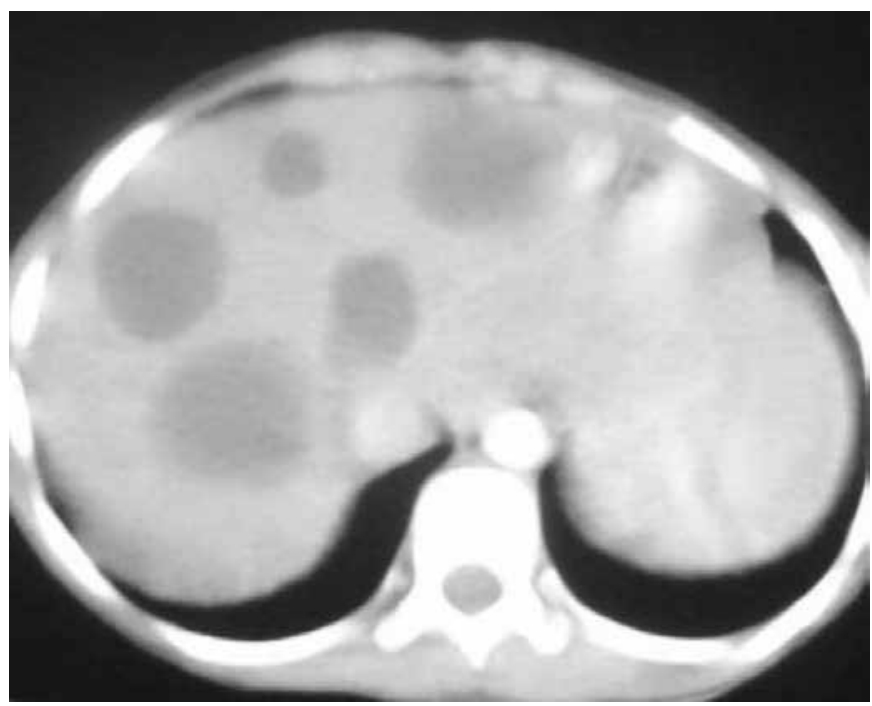




\section{Discussion}

Hydatid cyst is a serious health problem in undeveloped and developing countries and it has been known for many years. Humans are intermediate hosts in hydatid cyst. Adult parasites settle into small intestines of the final hosts which are carnivores. Eggs are spread in the environment via feces of these animals. They are transmitted to intermediate hosts through digestive tract. Embryos hatch and transfer into the blood from duodenum and may invade any tissue in the body. They involve liver frequently in adults while pulmonary involvement is primarily seen in children ${ }^{5}$. Cardiac involvement is quite rare.

Symptoms are dependent on the size of cysts and complications. The most common symptoms in pulmonary hydatid include cough, chest pain and dyspnea. If cyst is perforated, clear water (rock water) and membrane expectoration, hemoptysis and allergic reactions may occur ${ }^{6}$. Localized cysts in liver may remain asymptomatic for prolonged periods. As cysts develop, they may cause abdominal pain and swollen and become palpable. Pericardial cysts are generally asymptomatic. However, when rupture occurs they may cause acute tamponade and become life threatening. Besides tamponade, another serious complication of pericardial cysts is acute myocardial infarction.

Diagnosis of hydatid cyst is made based on main radiological examinations. Serological investigations are limited in diagnosis. Non invasive imaging techniques are used such as plain thoracic $\mathrm{x}$-ray graphy and Computed Tomography (CT) for the diagnosis of pulmonary cysts, abdominal USG and CT for hepatic cysts and echocardiography, CT and MRI for cardiac cysts. Transthoracic echocardiography has a high sensitivity in the diagnosis of intracardiac cysts. Some authors recommend routine echocardiography use for cases of pulmonary and hepatic cysts ${ }^{6}$. We used thoracic $x$-ray graphy, CT, MRI and echocardiography for our patient.

Although hydatid cyst is generally a benign lesion, it presents a serious risk of morbidity and mortality as a result of causing compression, becoming ruptured and causing anaphylaxis. Therefore, surgical treatment is indicated following the diagnosis ${ }^{7}$.

Thoracotomy is the best procedure to remove hydatid cyst in the treatment of pulmonary hydatid cyst. Cystotomy and capitonnage are the frequently used treatment methods for pulmonary hydatid cyst, as we also preferred. The main treatment is surgery in hepatic hydatid cyst. Cystic fluid is drained in the surgical operation and agents such as formalin, hypertonic saline, cetrimide, hydrogen peroxide, povidone-iodine and silver nitrate as scolicidal agents are injected into the cysts with a hold time of 15 minutes achieving death of scolex. Percutaneous needle aspiration may be used successfully in the treatment of Grade I and II hepatic hydatid cyst according to the classification of Gharbi ${ }^{5,8}$. However, the intervention performed for hepatic cyst by transdiaphragmatic route may prevent the patient from a second interventional or surgical procedure since right thoracotomy is mandatory for synchronous right pulmonary and subdiaphragmatic hepatic cysts. Most hepatic cysts can be reached by transdiaphragmatic route during right thoracotomy and the two separate procedure may be performed in one stage. The safety and acceptable morbidity of this method was demonstrated in several studies $^{8}$. In cases of right pulmonary and hepatic cysts presenting concomitantly, primary intervention should focus on pulmonary cyst by thoracotomy if it is not possible to reach the cysts located in liver by thoracotomy, because pulmonary cyst may be ruptured due to positive pressure ventilation under general anesthesia.

Although cardiac hydatid cyst is rare, it may threaten life according to the affected site. Complications resulting mortality includes anaphylactic shock, pulmonary, cerebral and peripheral artery embolism, acute coronary syndrome and arrhythmias. Therefore, surgical treatment is required to prevent future complications in patients with cardiac hydatid cyst, even if they are asymptomatic $^{9}$. Open heart surgery techniques or drainage for working heart may be performed according to the localization of the cysts $^{10}$. In our case, extracorporeal circulation was not required since the patient did not show 
myocardial invasion.

The main treatment of hydatid cyst is surgery. Chemotherapy with benzimidazole consisting of Mebendazole or Albendazole has not shown to be satisfactory yet ${ }^{11}$.

Medical treatment is performed for pulmonary cysts if cysts are small and uncomplicated and patients refuse or can not tolerate the procedure ${ }^{5}$. Since the cyst localized in the left lung of our patient was small and uncomplicated, Albendazole treatment was initiated.

In this presented case, transthoracic approach was used.

\section{References}

1. Karawi MA, Yasawy MJ, El Shiekh Mohamed AR. Endoscopic management of biliary hydatid disease: report on six cases. Endoscopy. 1991; 23: 278-281.

2. Peleg H, Best L-A, Gaitini D. Simultaneous operation for hydatid cysts of right lung and liver. J Thorac Cardiovasc Surg 1985; 90: 783-787.

3. Abid A, Khayati A, Zargouni N. Hydatid cyst of the heart and pericardium. International Journal of Cardiology. 1991; 32: 108-109.

4. Prousalidis J, Kosmidis $\mathrm{CH}$, Fahantidis E, Harlaftis N, Aletras O. Surgical treatment of multiple cystic echinococcosis. HPB. 2004; 6: $110-114$

5. Köktürk $O$, Gürüz $Y$, Akay $H$, Akhan $O$, Biber Ç, Çağırıcı U, et al. Toraks Derneği Paraziter Akciğer Hastalıkları Tanı ve Tedavi Rehberi 2002. Toraks 2002; 3: 1-16.

6. Karaoglanoglu N, Kürkcüoglu IC, Görgüner $M$, Eroglu $A$, Türkyılmaz A. Giant hydatid lung cysts. Eur J Cardiothorac Surg
Intervention for pericardial right pulmonary and hepatic cysts was performed in one occasion. The patient was discharged without complications.

In conclusion, hydatid cyst is still a serious health problem in many countries worldwide, as in our country. Surgical treatment is urgent in cases with cardiac cysts since life threatening complications may occur due to rupture of cysts into cardiac cavities and pericardium. However, duration and costs of hospital stay can be reduced by performing surgery in one occasion and with one incision in cases with multiple organ involvement.

2001;19: 914-917.

7. Ünal Ö, Etlik Ö, Arslan H, Kotan Ç, Tuncer I, Köseoğlu B. Percutaneous treatment of abdomınal hydatıdozıs. T Klin J Gastroenterohepatol 2002, 13:79-85.

8. Gezer S, Sirmali M, Göktürk F, Türüt H,Öz G, Taştepe I, et al. Single stage transthoracic approach to simultaneous right lung and liver hydatid cysts] S.D.Ü. Tip Fak. Derg. 2008:15:1-5.

9. Akar R, Eryilmaz S, Yazicioglu L, Eren NT, Durdu S, Uysalel A, et al. Surgery for cardiac hydatid disease: an Anatolian experience. Anadolu Kardiyol Derg 2003; 3: 238-44.

10. Meşe B, Uygur F, Erdoğan MB, Asil R, Yamak B. Surgical treatment of isolated cardiac echinococcosis, located in the right ventricular outflow tract. Anadolu Kardiyol Derg. 2006; 6: 372-3.

11. WHO Informal Working Group on Echinococcosis. Guidelines for treatment of cystic and alveolar echinococcosis in humans. Bull World Health Organ 1996; 74: 231-242. 